http://jurnaltarbiyah.uinsu.ac.id/index.php/raudhah

e-mail: jurnalraudhah@uinsu.ac.id

p-ISSN: 2338-2163

e-ISSN: $2716-2435$

\title{
Pengembangan Media Roda Putar Dengan Kardus Bekas Untuk Meningkatkan Kemampuan Bercerita Anak Usia 5-6 Tahun di Ra Al- Washliyah Kec. Ujung Padang Kab. Simalungun
}

\author{
${ }^{1}$ Masganti Sit \\ UIN Sumatera Utara \\ ${ }^{2}$ Hilda Putri Amallia \\ UIN Sumatera Utara \\ ${ }^{3}$ Sri Wahyuni \\ UIN Sumatera Utara
}

Article received : 10 Agustus 2021

Review process : 10 September 2021

Article accepted : 11 Oktober 2021

Article published : 01 Desember 2021

\begin{abstract}
Abstrak
Kemampuan bercerita anak usia 5-6 tahun di RA Al-Washliyah Ujung Padang selama ini cenderung monoton, hanya menggunakan media yang sama yaitu buku cerita saja. Penelitian ini bertujuan untuk Mengembangkan proses penggunaan, kepraktisan, media roda putar untuk meningkatkan kemampuan bercerita anak usia 5-6 Tahun. Penelitian dilakukan di RA Al-Washliyah Jalan Rivai Pekan Kecamatan Ujung Padang Kabupaten Simalungun. Ujung Padang, pada tanggal 7 September 2020, jumlah anak yang diteliti sebanyak 20 anak. Metode penelitian ini adalah R and $\mathrm{D}$ (Research and Development) yang diadaptasi dari model pengembangan Sugiyono. Data penelitian ini diperoleh menggunakan angket validasi dari ahli desain media dan ahli materi, serta menggunakan lembar observasi. Dari hasil uji kelayakan yang dilakukan oleh validator media dengan persentase $100 \%$ dengan kategori sangat layak. Hasil uji kelayakan yang dilakukan oleh validator materi mendapatkan persentase $90 \%$ dengan kategori sangat layak. Hasil uji coba anak pada tahap I persentase kemampuan bercerita $20 \%$, pada uji coba tahap II persentase kemampuan bercerita $65 \%$. Pada kemampuan bercerita anak meningkat dengan klasifikasi sangat tinggi memperoleh rata-rata skor 71 , sehingga media roda putar kita dapat dikatakan efektif untuk meningkatkan kemampuan bercerita anak.
\end{abstract}

Kata Kunci: Media Roda Putar, Kemampuan Bercerita Anak Usia Dini

\section{Abstract}

The storytelling skills of children aged 5-6 years at RA Al-Washliyah Ujung Padang tend to be monotonous, only using the same media, namely story books. This study aims to develop the process of using, practicality, swivel wheel media to improve the storytelling ability of children aged 5-6 years. The research was conducted at RA Al-Washliyah Jalan Rivai Pekan, Ujung Padang District, Simalungun Regency. Ujung Padang, on September 7, 2020, the number of children studied was 20 children. This research method is $R$ and D (Research and Development) which is adapted from Sugiyono's development model. The research data was obtained using a validation

Pengembangan Media Roda Putar Dengan Kardus Bekas Untuk Meningkatkan Kemampuan Bercerita Anak Usia 5-6 Tahundi Ra Al- Washliyah Kec. Ujung Padang Kab. Simalungun 
http://jurnaltarbiyah.uinsu.ac.id/index.php/raudhah

e-mail: jurnalraudhah@uinsu.ac.id

p-ISSN: 2338-2163

e-ISSN: $2716-2435$

questionnaire from media design experts and material experts, and using observation sheets. From the results of the feasibility test conducted by the media validator with a percentage of $100 \%$ with a very feasible category. The results of the feasibility test conducted by the material validator get a percentage of $90 \%$ with a very decent category. The results of the trial of children in stage I the percentage of storytelling ability was $20 \%$, in the trial stage II the percentage of storytelling ability was $65 \%$. In children's storytelling ability increased with a very high classification obtaining an average score of 71 , so that our rotating wheel media can be said to be effective in improving children's storytelling abilities.

Keywords: Spin Wheel Media, Early Childhood Storytelling Ability

\section{A. PENDAHULUAN}

Salah satu kegiatan yang dapat mengembangkan bahasa di Taman Kanak-Kanak yaitu melalui bercerita. Menurut Hidayat, bercerita merupakan aktivitas menuturkan sesuatu yang mengisahkan tentang perbuatan, pengalaman atau kejadian yang sungguh-sungguh terjadi maupun hasil rekaan. Bercerita dapat dilakukan dengan berbagai kegiatan atau berbagai media. Salah satunya adalah dengan menggunakan media roda keberuntungan. Media adalah medium/pelantara yang dapat mempengaruhi sikap, nilai, emosi dan mampu membangkitkan minat anak dalam proses kegiatan pembelajaran, dan juga dapat membantu menggabungkan pengalaman belajar yang baru dengan yang sebelumnya.

Kemampuan bercerita anak usia dini dimulai dengan membacakan buku-buku cerita kepada anak. Dengan sering membacakan buku cerita anak akan paham bahwa tiap huruf dapat dirangkai membentuk suku kata atau kosa kata. Kemampuan bercerita anak usia 5-6 tahun pada usia ini anak dituntut untuk berinteraksi dengan lingkungan agar perkembangan bahasanya semakin baik. Anak mampu memahami pembicaraan orang lain dan mampu mengungkapkan pikirannya. Menurut Ginnis, media roda putar atau keberuntungan adalah roda yang dibagi menjadi sektor-sektor sejumlah kartu pertanyaan. Media ini adalah permainan dengan keunggulan yang menantang, seperti game show di TV yang sangat familiar, dan memotivasi sebagian besar peserta didik. Kebutuhan akan media pembelajaran yang dapat menstimulasi kemampuan anak secara maksimal, mengingat pembelajaran PAUD berbeda dengan pembelajaran di tingkat pendidikan yang lebih tinggi.

Bercerita menggunakan media roda putar pada anak usia dini disini dengan menggunakan beberapa langkah-langkah yaitu: (1) Guru memberikan pengarahan atau penjelasan bagaimana memainkan media roda putar, (2) Kemudian siswa memutar media untuk menentukan siapa yang mendapatkan gambar yang ada di roda putar, (3) Selanjutnya, bagi siswa yang dapat akan menceritakan tentang sebuah gambar tersebut. Tujuan bercerita dengan menggunakan media roda putar pada anak usia 5-6 tahun adalah agar memperlancar kosa kata anak, terbiasa untuk bercerita,

Pengembangan Media Roda Putar Dengan Kardus Bekas Untuk Meningkatkan Kemampuan Bercerita Anak Usia 5-6 Tahundi Ra Al- Washliyah Kec. Ujung Padang Kab. Simalungun 
http://jurnaltarbiyah.uinsu.ac.id/index.php/raudhah

e-mail: jurnalraudhah@uinsu.ac.id

p-ISSN: 2338-2163

e-ISSN: 2716-2435

mendorong anak untuk bercerita dan dapat mengekspresikan dan menceritakan tentang sebuah gambar. Sehingga anak tidak merasa malu untuk bercerita dan dapat mengembangkan bahasa anak.

Berdasarkan hasil observasi yang dilakukan di RA Al-Washliyah, upaya guru dalam meningkatkan kemampuan bercerita sudah dilakukan. Salah satunya yaitu dengan menggunakan media buku cerita. Namun pada kenyataannya, ketika guru menggunakan media buku cerita anak kurang aktif, merasa bosan, kurang mendengarkan apa yang diceritakan oleh guru, kemudian ketika ditanya tentang apa yang ia dengar dan menceritakan kembali anak belum bisa dari situlah kemampuan bercerita anak masih belum berkembang. Kemudian kegiatan pembelajaran yang dilakukan guru masih kurang menarik karena hanya menggunakan media buku cerita saja, kurang kreatifan guru untuk memilih media yang cocok, belum tersedianya media roda putar untuk meningkatkan kemampuan bercerita anak usia 5-6 tahun di RA Al-Washliyah.

Maka dari itu peneliti akan mencoba menggunakan media lain yaitu media roda putar yang belum pernah dilakukan oleh guru. Peneliti merasa yakin bahwa dengan menggunakan media roda putar tersebut akan membawa suasana belajar anak yang menyenangkan, anak akan tertarik, aktif, memungkinkan anak untuk berkembang kreativitasnya, bersemangat dalam melakukan pembelajaran, mampu menceritakan kembali apa yang ia dengar. Suasana belajar yang menyenangkan akan membawa dampak motivasi anak yang tinggi untuk menjadikan suatu faktor penentu keberhasilan anak dalam mencapai hasil yang lebih baik.

Penelitian yang dilakukan oleh Elisabeth Tantiana Ngura yang berjudul "Pengembangan Media Buku Cerita Bergambar Untuk Meningkatkan Kemampuan Bercerita Dan Perkembangan Sosial Anak Usia Dini di Tk Maria Virgo Kabupaten Ende”. Hasilnya media buku cerita bergambar layak dan efektif untuk meningkatkan kemampuan bercerita dan perkembangan sosial anak (Elisabeth Tantiana Ngura ,2018)

Penelitian yang dilakukan oleh Indra Jaya yang berjudul "Pengaruh Menggambar bebas Terhadap Kemampuan Bercerita Anak’. Hasilnya terdapat pengaruh yang signifikan dengan menggunakan gambar dari hasil menggambar bebas dapat mempengaruhi kemampuan bercerita anak (Indra Jaya, 2017)

Penelitian yang dilakukan oleh Deartia Ayunda, Rivda Yetti, Indra Yeni yang berjudul "Pengaruh Media Roda Keberuntungan Modifikasi Terhadap Kemampuan Mengenal Angka Di Taman Kanak-Kanak". Hasilnya adanya pengaruh media roda keberuntungan terhadap kemampuan mengenal angka, dilihat dari ketika anak bisa menghubungkan angka ke benda lainnya dan

Pengembangan Media Roda Putar Dengan Kardus Bekas Untuk Meningkatkan Kemampuan Bercerita Anak Usia 5-6 Tahundi Ra Al- Washliyah Kec. Ujung Padang Kab. Simalungun 
http://jurnaltarbiyah.uinsu.ac.id/index.php/raudhah

e-mail: jurnalraudhah@uinsu.ac.id

p-ISSN: 2338-2163

e-ISSN: 2716-2435

menghitung jumlah kartu gambar dengan benar serta mengenal bentuk (Deartia Ayunda, Rivda Yetti, Indra Yeni, 2019)

Jadi dapat disimpulkan bahwa jurnal pertama masih ada anak yang belum bisa bercerita dengan menggunakan buku gambar secara baik. Lalu, peneliti mencoba dengan media lain yaitu menggunakan media buku cerita bergambar. Dengan media ini anak dapat melatih kemampuan berbahasa dan juga sosial anak. Jurnal kedua dapat disimpulkan bahwa guru hanya menggunakan majalah atau buku cerita saja, tidak adanya variasi dari guru sehingga kegiatan bercerita terkesan monoton, anak merasa bosan dan kurang optimal. Maka mencoba dengan menggambar dan hasilnya terdapat pengaruh yang signifikan dengan menggunakan gambar dari menggambar bebas. Kemudian dari jurnal ketiga ini menggunakan media roda keberuntungan terhadap kemampuan mengenal angka. Disini dilihat adanya pengaruh dari media kepada anak. Pengaruhnya, anak dapat mengenal angka, kemudian dapat menghitung dan mengenal bentuk dengan baik dan benar. Sebelumnya anak masih ada yang belum dapat mengenal angka, setelah dilakukan dengan media roda keberuntungan membantu anak mengenalnya dengan baik dan benar.

\section{B. METODE PENELITIAN}

Metode penelitian yang digunakan dalam penelitian ini adalah penelitian $\mathrm{R}$ and $\mathrm{D}$ (Research and Development). Penelitian ini merupakan model penelitian $\mathrm{R}$ and D (Research and Development) merupakan metode penelitian yang menghasilkan produk dan menguji keefektifan dari penggunaan produk tersebut melalui uji coba penelitian. Strategi penelitian ini pengembangan menurut sugiyono yaitu sebagai berikut: (1) potensi dan masalah; (2) pengumpulan data; (3) desain produk; (4) validasi desain; (5) revisi produk I; (6) uji coba produk; (7) revisi produk II; (8) uji coba pemakaian; (9) revisi produk; dan (10) produksi masal. Penelitian ini akan dilaksanakan di RA Al-Washliyah Jalan Pekan Ujung Padang Kecamatan Ujung Padang Kabupaten Simalungun. Adapun waktu pelaksanaan penelitian ini, yaitu semester genap. Subjek penelitian ini yaitu: Subjek penelitian ini yaitu anak kelompok B usia 5-6 tahun yang berjumlah 1 kelas 20 anak terdiri 9 perempuan 11 laki-laki dan 2 orang guru. Objek dalam penelitian ini yaitu media roda putar.

Teknik analisis data dilakukan dengan Uji kelayakan media roda putar untuk meningkatkan kemampuan bercerita anak menggunakan skor persentase angket validator ahli (ahli media dan ahli materi) yaitu:

Pengembangan Media Roda Putar Dengan Kardus Bekas Untuk Meningkatkan Kemampuan Bercerita Anak Usia 5-6 Tahundi Ra Al- Washliyah Kec. Ujung Padang Kab. Simalungun 
http://jurnaltarbiyah.uinsu.ac.id/index.php/raudhah

e-mail: jurnalraudhah@uinsu.ac.id

p-ISSN: 2338-2163

e-ISSN: 2716-2435

$P=\frac{f}{n} \times 100 \%$

Keterangan:

$\mathrm{P}$ :persentase skor

$\mathrm{f}$ :jumlah skor yang diperoleh

$\mathrm{n}$ : jumlah skor maksimum.

Teknik analisis data juga dilakukan dengan Uji keefektivan kemampuan kemampuan bercerita anak dianalisis menggunakan tabel klasifikasi keefektivan. Namun sebelum diuji efektivitasnya maka harus diketahui dulu peningkatan hasil belajar dengan rumus gain score, yaitu:

\section{Gain score = observasi awal - observasi akhir}

Keterangan:

Gain score : skor peningkatan

Observasi awal : skor tes awal

Observasi akhir : skor tes akhir

\section{HASIL TEMUAN DAN PEMBAHASAN}

1. Data Validasi Ahli Media

Ahli media yang menguji validator dalam penelitian pengembangan ini adalah ibu Sri Wahyuni, M.Psi, peneliti memilih beliau sebagai ahli media. Pengambilan data ahli media dilakukan pada tanggal 24 Maret 2021 diperoleh dengan cara memberikan produk "pengembangan media roda putar" beserta lembar penilaian yang berupa angket. Pada validasi ahli media presentase yang didapatkan $100 \%$ dengan demikian dapat dinyatakan bahwa menurut ahli media, pada tahap validasi media roda putar yang dikembangkan dari aspek kelayakan media mendapatkan ketegori sangat layak.

2. Data Validasi Ahli Materi

Ahli materi yang menguji validator dalam penelitian pengembangan ini oleh Ibu Susiah Amni, MA, M.Psi, peneliti memilih beliau sebagai ahli materi. Pengambilan data ahli media dilakukan pada tanggal 25 Maret 2021 diperoleh dengan cara memberikan produk “pengembangan media roda putar" beserta lembar penilaian yang berupa angket. Pada validasi ahli materi persentase yang didapatkan $90 \%$ dengan demikian dapat dinyatakan bahwa pada tahap validasi produk pengembangan media roda putar yang dikembangkan dari aspek kelayakan produk mendapatkan kategori sangat layak.

Pengembangan Media Roda Putar Dengan Kardus Bekas Untuk Meningkatkan Kemampuan Bercerita Anak Usia 5-6 Tahundi Ra Al- Washliyah Kec. Ujung Padang Kab. Simalungun 
http://jurnaltarbiyah.uinsu.ac.id/index.php/raudhah e-mail: jurnalraudhah@uinsu.ac.id

3. Hasil penilaian guru terhadap produk

Penilaian kelayakan produk ini dilakukan oleh salah satu guru di RA Al-Washliyah yaitu ibu Rizky Lestari, S.Pd. Berikut adalah hasil penilaian produk yang dikembangkan.

\begin{tabular}{|l|l|l|c|}
\hline No. & Indikator Penilaian & Skor & Persentase \\
\hline 1. & Desain Produk & 20 & $100 \%$ \\
\hline 2. & Aspek Materi & 22 & $90 \%$ \\
\hline \multicolumn{2}{|l|}{ Total } & 52 & $190 \%$ \\
\hline \multicolumn{2}{|l|}{ Rata-rata } & $3,8 \%$ & $95 \%$ \\
\hline \multicolumn{2}{|c|}{ Keterangan } & \multicolumn{2}{|c|}{ Sangat Layak } \\
\hline
\end{tabular}

Tabel 1. Hasil Penilaian Kelayakan Produk "Pengembangan Media Roda Putar"

Berdasarkan tabel 1. diatas dapat diketahui bahwa penilaian produk oleh guru RA AlWashliyah diperoleh kelayakan persentase terhadap desain produk yaitu $100 \%$. Pada aspek materi mendapatkan persentase produk yaitu 90\%. Jumlah rata-rata skor pada penilaian produk sebesar 3,8\% dengan persentase kelayakan 95\%. Maka dapat disimpulkan bahwa produk ini sangat layak.

a) Desain Produk

Revisi dilakukan setelah produk "pengembangan media roda putar" diberi penilaian, dan kritikan terhadap kualitas materi dan media pada roda putar yang dikembangkan untuk meningkatkan kemampuan bercerita anak.

1) Gambar Produk

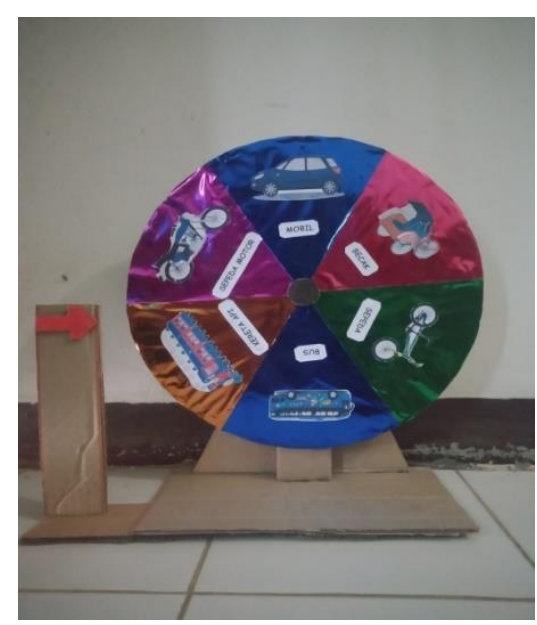

Gambar 1. Hasil Produk Media Roda Putar

Pengembangan Media Roda Putar Dengan Kardus Bekas Untuk Meningkatkan Kemampuan Bercerita Anak Usia 5-6 Tahundi Ra Al- Washliyah Kec. Ujung Padang Kab. Simalungun 
http://jurnaltarbiyah.uinsu.ac.id/index.php/raudhah e-mail: jurnalraudhah@uinsu.ac.id

b) Hasil Uji Coba Tahap I

Hasil observasi yang dilakukan penulis dan guru kelompok B di RA AlWashliyah menunjukkan bahwa aktivitas penulis selaku guru selama penelitian tahap I dalam seluruh kegiatan pembelejaran terkhusus pada Peningkatan Kemampuan Bercerita anak. Hasil tersebut dapat dilihat dari tabel dibawah ini:

\begin{tabular}{|c|c|c|c|c|}
\hline No. & Skor Rata-Rata & Jumlah Anak & $\begin{array}{c}\text { Persentase } \\
\text { Nilai Anak }\end{array}$ & Keterangan \\
\hline 1 & $13-16$ & 4 & $20 \%$ & BSB \\
\hline 2 & $9-12$ & 8 & $40 \%$ & BSH \\
\hline 3 & $5-8$ & 8 & $40 \%$ & MB \\
\hline 4 & $0-4$ & 0 & 0 & BB \\
\hline \multicolumn{2}{|c|}{ Jumlah } & 20 & 100 & \\
\hline
\end{tabular}

Tabel 2. Rangkuman Hasil Uji Coba Kemampuan Bercerita Tahap I

c) Hasil Uji Coba Tahap II

Hasil observasi yang sudah dilakukan oleh penulis dan guru RA Al-Washliyah menunjukkan bahwa aktivitas penulis selaku guru selama penelitian tahap II dalam seluruh kegiatan pembelajaran terkhusus pada Peningkatan Kemampuan Bercerita Anak lebih meningkat dari tahap I. Hasil tersebut dapat dilihat dari tabel di bawah ini:

\begin{tabular}{|c|c|c|c|c|}
\hline No. & Skor Rata-Rata & Jumlah Anak & $\begin{array}{c}\text { Persentase } \\
\text { Nilai Anak }\end{array}$ & Keterangan \\
\hline 1 & $13-16$ & 13 & $65 \%$ & BSB \\
\hline 2 & $9-12$ & 7 & $35 \%$ & BSH \\
\hline 3 & $5-8$ & 0 & 0 & MB \\
\hline 4 & $0-4$ & 0 & 0 & BB \\
\hline \multicolumn{2}{|r|}{ Jumlah } & 20 & 100 & \\
\hline
\end{tabular}

Tabel 3. Rangkuman Hasil Uji Coba Kemampuan Bercerita Tahap II

d) Uji Keefektifan Kemampuan Bercerita Anak

Hasil penelitian dari uji coba penggunaan media roda putar pada tahap I dan tahap II dapat dilihat dari tabel berikut:

\begin{tabular}{|c|c|c|}
\hline $\begin{array}{c}\text { Penggunaan Media } \\
\text { Roda Putar }\end{array}$ & Uji Coba Tahap I & Uji Coba Tahap II \\
\hline BB & 0 & 0 \\
\hline MB & 16 & 0 \\
\hline
\end{tabular}

Pengembangan Media Roda Putar Dengan Kardus Bekas Untuk Meningkatkan Kemampuan Bercerita Anak Usia 5-6 Tahundi Ra Al- Washliyah Kec. Ujung Padang Kab. Simalungun 
http://jurnaltarbiyah.uinsu.ac.id/index.php/raudhah e-mail: jurnalraudhah@uinsu.ac.id

\begin{tabular}{|c|c|c|}
\hline BSH & 24 & 21 \\
\hline BSB & 16 & 52 \\
\hline Total Skor & 56 & 73 \\
\hline Rata-Rata & 2,8 & 3,65 \\
\hline Persentase & $70 \%$ & $91,25 \%$ \\
\hline
\end{tabular}

Tabel 4. Hasil Penelitian Pengembangan Media Roda Putar Tahap I dan Tahap II

Dari tabel 4. di atas dapat di uji keefektifan Media Roda Putar dalam meningkatkan kemampuan bercerita anak usia 5-6 tahun menggunakan rumus gain score, yaitu:

Gain skor $=\frac{\text { nilai sesudah-nilai sebelum }}{\text { nilai maksimum-nilai sebelum }} \times 100$

Gain skor $=\frac{73-56}{80-56} \times 100=\frac{17}{24} \times 100=71$

Dari hasil ini maka keefektifan pengembangan media roda putar untuk meningkatkan kemampuan bercerita anak usia 5-6 tahun memperoleh nilai rata-rata gain score 71 yang berarti $\mathrm{X}>37$ dengan klasifikasi sangat tinggi.

\section{SIMPULAN DAN SARAN}

Berdasarkan hasil dari validasi ahli dan peningkatan anak pada tahap I dan tahap II diperoleh beberapa kesimpulan: 1) Proses penggunaan Media Roda Putar melalui tujuh langkah: (a) potensi dan masalah dengan menggunakan buku cerita saja. Kehadiran media akan membantu anak untuk bercerita., (b) pengumpulan data menggunakn kuesioner atau angket yang diisi oleh ahlinya, yaitu ahli media dan ahli materi., (c) desain produk dilakukan dengan menyertai alat dan bahan kemudian menggunakan langkah pembuatannya, (d) validasi desain yaitu dengan validator ahli media dan validator ahli materi, (e) revisi produk dengan mengetahui kekurangannya. Kekurangan tersebut dilakukan perbaikan produk. Peneliti memperbaiki produk tersebut sesuai dengan saran dan penilaian validator, (f) uji coba produk bertujuan untuk mengetahui penggunaan media roda putar untuk meningkatkan kemampuan bercerita anak. Uji coba produk dilakukan dengan menggunakan evaluasi melalui indikator yang telah dirancang, (g) uji coba pemakaian dilakukan untuk satu kelas dengan observasi. Uji coba pemakaian ini dilakukan 2 kali pembelajaran pada hari yang sama tanpa jeda. 2) Penggunaan kardus bekas dalam pembuatan media pembelajaran ini dapat dikatakan bahwa sebagai bentuk pemanfaatan bahan bekas dan bentuk peningkatan kreativitas guru dalam penyediaan media pembelajaran yang lebih hemat dan praktis. 3) Uji kepraktisan atau uji keefektifan Media Roda Putar dari penelitian "Pengembangan Media Roda Putar" pada uji coba tahap I presentase

Pengembangan Media Roda Putar Dengan Kardus Bekas Untuk Meningkatkan Kemampuan Bercerita Anak Usia 5-6 Tahundi Ra Al- Washliyah Kec. Ujung Padang Kab. Simalungun 
http://jurnaltarbiyah.uinsu.ac.id/index.php/raudhah

e-mail: jurnalraudhah@uinsu.ac.id

p-ISSN: 2338-2163

e-ISSN: 2716-2435

kemampuan bercerita anak $20 \%$, pada uji coba tahap II presentase kemampuan bercerita anak 65 $\%$. maka keefektifan pengembangan media roda putar untuk meningkatkan kemampuan bercerita anak usia 5-6 tahun memperoleh nilai rata-rata gain score 71 yang berarti $\mathrm{X}>37$ dengan klasifikasi sangat tinggi. 4) Dari penelitian "Pengembangan Media Roda Putar" dilakukan II tahap, yaitu tahap I peningkatan kemampuan bercerita anak usia 5-6 tahun di peroleh nilai rata-rata 13,35\% dari 20 anak, 8 anak mulai berkembang (40\%), 8 anak berkembang sesuai harapan (40\%) dan 4 anak berkembang sangat baik (20\%). Pada tahap II peningkatan kemampuan bercerita anak usia 5-6 tahun di peroleh nilai rata-rata 13,85\% dari 20 anak, 7 anak berkembang sesuai harapan (35\%) dan 13 anak berkembang sangat baik (65\%). Kondisi ini menunjukkan bahwa kemampuan bercerita anak sudah efektif meningkat dengan rata-rata gain score 71 dengan klasifikasi sangat tinggi.

Berdasarkan peneliti pengembangan yang telah dilakukan, media roda putar untuk meningkatkan kemampuan bercerita anak tentu masih jauh dari kata sempurna. Oleh karena itu, beberapa saran pemanfaatan dan pengembangan produk lebih lanjut yang dibutuhkan adalah sebagai berikut: 1) Ada baiknya guru mengembangkan media yang dapat menarik anak agar hasil belajar dan pemahaman anak dapat meningkat. 2) Ada baiknya dilakukan penelitian lagi yang pengembangannya serupa namun dengan materi yang berbeda dan lebih baik lagi untuk menambah wawasan dunia pendidikan Indonesia. 3) Ada baiknya pihak sekolah dapat memfasilitasi para pendidik untuk mengikuti pelatihan pengembangan media guna memperluas wawasan. 4) Ada baiknya anak dapat menyalurkan kegiatan yang dapat mendorong anak untuk kreatif dan melakukan kegiatan yang menyenangkan. 5) Ada baiknya orang tua untuk selalu membantu mengembangkan kemampuan anak yaitu dalam bercerita dirumah.

\section{DAFTAR PUSTAKA}

Agusniatih, Andi, dan Jane M Monepa. 2019. Keterampilan Sosial Anak Usia Dini, Jawa Barat: Adu Publisher.

Anggraini, Putri. 2016. Pengembangan Media Roda Putar Untuk Meningkatkan Kemampuan Mengenal Bentuk Geometri Anak Usia 4-5 Tahun, Universitas Negeri Surabaya.

Arifin Zakaria, Zainal. 2016. Tafsir Inspirasi, Medan: Duta Azhar.

Fadilah. 2017. Bermain dan Permainan Anak Usia Dini, Jakarta: Kencana.

Fadillah, dkk. 2014. Edutainment Pendidikan Anak Usia Dini Menciptakan Pembelajaran Menarik, Kreatif, dan Menyenangkan, Jakarta: Kencana Prenadamedia Group.

Ginnis, Paul. 2008. Trik dan Taktik Mengajar, Jakarta: Indeks.

Pengembangan Media Roda Putar Dengan Kardus Bekas Untuk Meningkatkan Kemampuan Bercerita Anak Usia 5-6 Tahundi Ra Al- Washliyah Kec. Ujung Padang Kab. Simalungun 
http://jurnaltarbiyah.uinsu.ac.id/index.php/raudhah

e-mail: jurnalraudhah@uinsu.ac.id

p-ISSN: 2338-2163

e-ISSN: 2716-2435

Hanifah, Nurdinah, dkk. 2018. Prosiding Seminar Nasional Membangun Generasi Emas 2045 yang Berkarakter dan Melek IT dan Pelatihan Berpikir Suprarasional, Sumedang: Upi Sumedang Press.

Khairunnisa. 2017. Pengembangan Media Permainan Roda Putar Berbasis Website Untuk Keterampilan Membaca Bahasa Prancis Siswa Kelas Xi Sma Angkasa Adisutjipto, Universitas Negeri Yogyakarta.

Khadijah. 2016. Pendidikan Prasekolah, Medan: Perdana Publishing.

Khadijah. 2015. Media Pembelajaran Anak Usia Dini, Medan: Perdana Publishing.

Khadijah. 2016. Pengembangan Kognitif Anak Usia Dini Teori Dan Pengembangannya, Medan: Perdana Publishing.

Kustiawan, Usep. 2016. Pengembangan Media Pembelajaran Anak Usia Dini, Malang: Gunung Samudra.

Latif, Mukhtar. 2013. Orientasi Baru Pendidikan Anak Usia Dini Teori Dan Aplikasi, Jakarta: Kencana Prenada Media Group.

Maisarah. 2019. Metodologi Penelitian Pendidikan Pendekatan Kuantitatif, Medan: Akasha Sakti.

Risaldy, Sabil. 2015. Bermain, Bercerita \& Menyanyi Bagi Anak Usia Dini, Jakarta: Luxima Metro Media.

Sumiharsono, Rudi dan Hisbiyatul Hasanah. 2017. Media Pembelajaran, Mataram: Pustaka Abadi. Sugiyono. 2019. Metode Penelitian \& Pengembangan (Research and Development/R\&D), Bandung: Alfabeta.

Susanto, Ahmad. 2017. Pendidikan Anak Usia Dini (Konsep dan Teori), Jakarta: Bumi Aksara.

Trianto. 2011. Desain Pengembangan Pembelajaran Tematik Bagi Anak Usia Dini TK/RA \& Anak Usia Kelas Awal SD/MI, Jakarta: Kencana.

Tune Sumar, Warni dan Intan Abdul Razak. 2016. Strategi Pembelajaran Dalam Implementasi Kurikulum Berbasis Soft Skill, Yogyakarta: Deepublishing.

Pengembangan Media Roda Putar Dengan Kardus Bekas Untuk Meningkatkan Kemampuan Bercerita Anak Usia 5-6 Tahundi Ra Al- Washliyah Kec. Ujung Padang Kab. Simalungun 